\title{
Progress and Pitfalls in Women's Education in Turkey (1839-2017)
}

\author{
Ayşe Durakbaşa \\ University of Marmara ( retired $^{1}$ ) \\ Funda Karapehlivan \\ (Independent Researcher ${ }^{2}$ )
}

\begin{abstract}
Girls' education and women's enlightenment have been key elements of the Kemalist Republic (1923), which claimed to face towards the highest level of civilization and treated women as the symbols of a modernized secular Turkish nation-state and society. However, the official ideological and cultural principles of the education system in Turkey underwent dramatic transformations. Education policies under the AKP rule have been shaped by a combination of neoliberalism, conservatism and Islamism. Consequently, the education system has changed rapidly especially during the last six years. Since early 2012, Turkish education system suffered radical changes with tremendous implications for women's education in particular and gender equality in general. In this article, after a general review and commentary about the development of women's education during the different stages of the Republic, we will concentrate on the process of Islamization of education in recent Turkey especially concerning consequences for girls and women. This brings along the need for a closer look on the clerical schools, so called Imam Hatip Schools in which apart from the conventional High School Curriculum Islamic teachings is provided to students.
\end{abstract}

Key Words: Women's Education, Turkey, Gender Equality, Islamization of education

\section{Progrès et pièges de l'éducation des femmes en Turquie (1839-2017)}

Résumé: L'enseignement des filles et la formation des femmes ont été les éléments clés de la République Kemalist (1923), qui a essayé d'augmenter le niveau de civilisation en Turquie en traitant les femmes comme des symboles d'une société modernisée dans un contexte d'Étatnation turc laïc. Cependant, les principes idéologiques et culturels officiels du système éducatif turc ont subi des transformations dramatiques. Les politiques éducatives conformément à l'autorité d'AKP (Parti de la justice et du développement) ont été formées par une combinaison de neoliberalism, conservatisme et Islamisme. En fait, le système éducatif a changé très vite, particulièrement pendant les six dernières années. Depuis l'année 2012, le système éducatif turc a subi des changements radicaux avec des implications énormes, en particulier, pour l'enseignement de femmes et pour l'égalité des sexes. Dans cet article, après d'un bilan général et d'un commentaire autour du développement de l'éducation de femmes pendant les différentes étapes de la République, nous nous concentrerons sur le processus d'Islamisation de l'enseignement en Turquie, particulièrement nous nous intéresserons aux conséquences pour les filles et les femmes. Cette situation nous amène au besoin d'un coup d'oeil sur les écoles 
cléricales en Turquie, appelées des Écoles d'Imam Hatip, dans lesquelles en dehors du Programme d'études conventionnel des lycées, les enseignements islamiques étaient fournis aux étudiants.

Mots-clés: Éducation de femmes, Turquie, Égalité des sexes, Islamisation de l'éducation

\section{Avances y dificultades en la educación de las mujeres en Turquía (1839-2017)}

Resumen: La educación de niñas y la ilustración de la mujer han sido elementos clave de la República Kemalista (1923) que pretendía elevarse al los niveles más altos de la civilización y proyectaba a las mujeres como símbolos del modern Estado-nación y de la sociedad laica en Turquía. Sin embargo, los principios ideológicos y culturales oficiales del sistema educativo sufrieron transformaciones dramáticas. Las políticas educativas bajo el gobierno del AKP han sido moldeadas por una combinación de neoliberalismo, conservadurismo e islamismo. En consecuencia, el sistema educativo ha cambiado rápidamente, especialmente durante los últimos seis años. Desde principios de 2012, el sistema educativo turco sufrió cambios radicales con enormes implicaciones para la educación de las mujeres en particular y la igualdad de género en general. Después de una revisión general y un comentario sobre el desarrollo de la educación de las mujeres durante las diferentes etapas de la República, este artículo se centra en el proceso de islamización de la educación en la Turquía reciente, especialmente en relación con las consecuencias para las niñas y las mujeres. Esta tarea requiere echar una mirada más detallada a las escuelas clericales, Ilamadas Escuelas Imam Hatip, en las cuales, junto al plan de estudios convencional, se imparte una enseñanza islámica a los estudiantes.

Palabras clave: Educación de Mujeres, Turquía, Igualdad de Género, Islamización de la Educación

\section{Introduction}

Since 2002, Turkey has been ruled by AKP governments (Justice and Development Party) which have made Islamic religious sentiments of the electorate their first priority. Turkey's venture in Westernization and modernization has a long history and women have always been at the core of public debates and discussions. In this article, after we summarize the first phase of modernization in the late Ottoman period and its impact on women's education, we concentrate on the main educational models during the early Republic which aimed at raising the education level of the young and the adults with a perspective of gender equality and a particular interest in the education of women as mothers with Republican ideals. It is evident in the speeches and acts of Kemal Atatürk, the founder of the Turkish Republic, that he wanted to shape modern Turkey with the image of the "new woman" on the public scene. Women have benefitted from the Kemalist reforms and also, in the face of resistance against Kemalism, they have been at the core of political ideologies, public debate and development plans. In the present paper, we try to comment on the impact of political revival of Islam and Islamic movements under the political tutelage of AKP in Turkey, in terms of the impact on women's education in particular and gender equality in general. 


\section{Ottoman Women's Education}

Ottoman women had to wait a long time, until the beginning of the 20th century to get access to widespread formal education; before then, young women from the upper-class, elite households were educated either by private tutors in their home or in foreign missionary schools.

Women's education became a topic of public debate and discussion in the Ottoman press at the end of the 19th century; for example, the first newspaper published in Ottoman script, Terakki (1868) also had a pamphlet called Muhaderat (1869) for its women readers. Şefika Kurnaz acknowledged 13 different women's journals during the period 1868-1900 (Kurnaz, 1991, pp. 3944). Women's organizations and women's press became even more volatile in the second Constitutional Period after 1908, which made scholars like Serpil Çakır name it as "Ottoman women's movement" (Çakır, 1990; Çakır, 2007, pp. 68-73), a nascent feminism in Ottoman land at the beginning of the 20th century. Advocates of the woman question analysed the flaws in women's status in Ottoman society and called for a more egalitarian family life, the ban of polygamy, equal rights in divorce, most important of all, access to education for girls so that children could be brought up by educated mothers and widowed or divorced women could earn their living on decent grounds (Çakır, 1990; Kurnaz, 1991). Hanımlara Mahsus Gazete (Journal for Ladies, which advocated being a good wife, mother and a good Muslim) and Kadınlar Dünyası (Women's World), the publication of the women's organization named Müdaafa-i Hukuk-u Nisvan Cemiyeti (1913) (Society for Defense of the Rights of Women), a vehement advocate of the rights of education and public participation and employment for women were the two outstanding women's journals of the time. Çakır specified 40 women's associations in the period 1909-1923, which functioned in the area of philanthropy, education, cultural activities, political participation and women's rights (Çakır, 1991, p. 139; Çaha, 2010, p. 122). Women's education was a common topic for the Turkists, Westernists and the Islamists who held different political views, but had a consensus that Ottoman women's status had to be improved through education for the sake of the well-being of the family and society.

The Tanzimat Edict (1839), which is considered a mile-stone in the history of modernization of the Ottoman Empire, declared equal citizenship rights regardless of religion, ethnic identity and gender. Modernizing reforms in the administrative and legal structure of the Ottoman state also made necessary a renovation of educational institutions. Starting with Tanzimat, educational reforms were carried out and new schools were opened within a modernist, Westernist perspective, inspired by the excelling of the positive sciences in the West. Women's education also became an essential area of reform as part of these modernization attempts to save the Ottoman state and society from ignorance and backwardness. The secondary level of schools (rüştiye) were opened for girls in 1859. In 1870, Darülmuallimat (college for women teachers) was opened in response to the growing need for female teachers to teach girls at rüştiye. The first graduates of Darülmuallimat also became the first teachers as graduates of formal education and the first female civil servants of civil state education (Gelişli, 2014 , p. 2). In 1842, training courses for nurses started in the Medical College. The Ministry of Education in the Second Constitutional Period (1908-1923) aimed at opening idadi's or high schools for girls and in 1911 Istanbul Girls' High School was opened. In 1914 inas Darulfünunu (University for women) and Inas Sanayi-i Nefise Mektebi for the education of women in the area of fine arts started working (Çaha, 2010, pp. 106-109). 
Many topics such as co-education, the enrolment of women to medicine and other branches of natural and social sciences as well as for becoming teachers in the first place and later civil servants, members of various crafts and professions became part of public discussion and debate in the lively political and cultural environment of the Constitutional Period. An interesting pioneering action of the women students in Inas Darülfunun was their boycott of the single-sex education after which the first trials of mixed education started in the university. The female students were allowed to enter the Faculty of Law in 1921/22 and the Medical College in 1922/23 (Gelişli, 2014, p. 2). These progressive attempts by the leading political party of the Union and Progress laid the foundation for the radical reforms during the early Republic. In the reports of the Educational Congress convened in 1921, emphasis was laid on practical, technical education and on practical knowledge for the girls in home keeping.

\section{Women's Reforms and Education in the Republic}

The reports of the scientific educational committees (Heyet-i Ilmiye), successively convened in 1923, 1924 and 1925, outlined the principles of education to teach the young (both girls and boys) the core topics of National Culture, namely, National Language, National History, Literature and Music. The Ministry of Education started a campaign for widespread education for people of age 16-45 in Millet Mektepleri schools, especially after 1928 when the alphabet was changed and those literate in Arabic script had to learn the new Latinized Turkish alphabet. More than 1.5 million adults obtained certificates from these schools between 1928 and 1950 . The literacy rate which was only 10.7\% in 1927, was raised to $19.5 \%$ in 1935 and to $22.4 \%$ in 1940 (Akyüz, 2014, pp. 404-405).

Mustafa Kemal as a leader promoted women's rights and realized many reforms in the area of women's education as well as family law. The New Civil Code was adopted from the Swiss Civil Code to the Turkish-Muslim social context in 1926. His aim was to include women as citizens in the overall mobilization of human resources for a more developed society through the spread of national education. In 1924, mixed education was accepted in the primary schools, i.e. the first five years of schooling, considered as the basic compulsory educational level. On March 22, 1926 and June 10, 1933, laws about national education and its organization by the Ministry of Education were passed. Not only primary education but also secondary education were freed from charge and thereby co-education became the principle in recruitment of students, a progressive leap in education which also secured more efficient use of various facilities, resources and human capital (Arat, 1999, pp. 158-159; Gelişli, 2014, p. 4). The Unification of Education Law (1924) promoted uniformity of a secular and Westernized education system aiming at the socialization of new generations with a national/political consciousness of being citizens of a modern secular state (Arat, 1999).

The Kemalist Republic put many educational reforms into practice in order to raise the literacy and schooling rates among the general population and also women. Also in the Era of Planned Development, starting from the first Five Year Plan (1963-1967), high rates of female illiteracy and drop-out rates of girls in schooling were specified as major problems to be solved. In Turkey, literacy was raised to 48\% from 19\% in the period between 1930 and 1965 (Gelişli, 2014, p. 123).

Different models of single-sex and mixed-sex education at the junior and senior levels of secondary education (middle school and lycee) after primary school education (being mixed) 
were implemented during the early Republican Era (1923-1946). In 1923, there were only 9 high schools for girls and 14 high schools for boys. In the academic year 1934-1935, it was decided that in the 19 lycees in the provinces, co-education would be implemented (Akyüz, 2014, pp. 398399).

At first, the enrolment of girls in the co-educational high schools was very low and most of the female students attended sex-segregated high schools such as lycees for Girls or the socalled Girls' Institutes. As Arat (1999, pp. 170-172) maintains, based on her interviews with women of the first generation of the Republic, school administrators and teachers were cautious about the relationships of boys and girls and their control over the students' outfits and social conduct extended beyond the school. A special attention to sexual modesty in outlook and behaviour was demanded from the girls. On the other hand, the schools were to function as new social settings where girls and boys could learn how to relate in a civilized manner. Hence, students from both sexes were brought together to participate in official ceremonies and sports spectacles on national holidays (Arat, 1999, pp. 170-172). In fact, the photographs of such scenes make the most striking testimonies of radical modernization in the early Republic.

National mobilization of human resources also called for the improvement of the status of women in terms of access to education and encouragement of women into various spaces of social life and public spheres of activity. Hence, women in Turkey were granted suffrage in local elections in 1930 and in national elections in 1934. Due to the fact that positivism and positivist sciences were highly valued in the early Republic, women as well as men were encouraged to study in natural sciences. Moreover, there was no reference to an inherent intellectual weakness of the female; on the contrary, girls were encouraged to believe that they could study everything and pursue any career. Mustafa Kemal played the role of the Father of Turks and of the headmaster to all Turkish people promoting his adopted daughters to get higher education in different disciplines. For example, he encouraged one of them, Sabiha Gökçen, to study aviation and become a war pilot, which had not been open to women before that time (Arat, 1999, pp. 177-178). Hence, in the 1946-1947 academic year, the percentage of female academics in the natural sciences was $44 \%$, while in the humanities they made only $22 \%$ of the total number (Köker, 1988). A study on the rates of participation of Turkish women in the professions such as medicine, law, pharmacy, and even in natural sciences and engineering shows that women in Turkey reached extraordinary numbers when comparing to most of the developed countries. In 1970, the percentage of women doctors reached 14\%, being even higher than in the USA with only $10 \%$. Among the engineers it was $13.5 \%$, which was only $8.6 \%$ in the USA. In addition, the percentage of architects with 39\% was much higher figure than in the USA. $28 \%$ of all lawyers were female which was again higher than in USA with $22.7 \%$. A definitely striking figure was the great number of female dentists in Turkey (39\%) compared to the USA (9\%) (Öncü, 1979). ${ }^{3}$

Oral history narratives and memoirs by the first generation of Republican women show that young women felt supported by the young Republic, i.e. the modernizing nation-state, and were encouraged into education and undertaking professional roles in public life. It is also worth mentioning that the first generation of professionally educated women of the Republic considered themselves as privileged and did not mention any sort of gender related inequality (Durakbaşa, 1987; Durakbaşa, 1998).

According to the latest country report on Turkey, gender distribution in different disciplines of higher education are relatively balanced when compared to the average of the 
other OECD countries. A striking figure is the high number of female students who have entered the IC branches (29\%), which is above the OECD average of $19 \%$. In the social sciences, journalism and information sciences the percentage of female students is $52 \%$ and in management, administration and law it is $44 \%$, while the OECD averages are $64 \%$ and $54 \%$, respectively. In health and social services, while the percentage of female students is $67 \%$ in Turkey, the OECD average is 76\% (OECD EAG Country Report, 2017). We believe the sexual egalitarianism of the Kemalist Republic has had its trace on female students' choices of subjects.

The indicators about women's status in Turkey display a complex picture, puzzling at first sight, because they present a combination of highly favourable percentages of women among the highly educated professionals which hint at gender equality, and very poor statistical figures in relation to illiteracy, lack of schooling, or any vocational skills among women of rural Turkey and poorer social classes which increase the gap between genders.

Despite all attempts, illiteracy rates among the female population have been a persisting problem for a long time. The percentages of illiteracy among the female population show variation according to geographical regions in Turkey and are always higher in the Eastern Black Sea Region, in Eastern and South-eastern Anatolia. In 1998, for example, the illiteracy rate was $42 \%$ in Eastern Anatolia, 55\% in South-eastern Anatolia, and Şırnak as a province in the southeast had $85 \%$, the highest percentage of illiterate women (Deniz, 2001, p. 163).

\section{Girls' Institutes}

The first technical training schools for girls, so called KIz Sanayi Mektepleri (Industrial Schools for Girls), opened in 1860 under the reign of II. Abdülhamit are considered as the predecessors of the Girls' Institutes in the Republican Era. However, it seems that these schools in the late Ottoman era were designed for lower class or single or widowed women who had to earn their living in the conditions of great numbers of lost male members of households during the various wars. Girls' Institutes (KIz Enstitüleri) set up in 1928, however, targeted girls' education as enlightened mothers, wives and housewives of the modernizing elite and the middle classes first in the main cities and then in some provincial towns of Turkey. Hence, we see the attempt by the Kemalist modernizers to somehow educate women from different sectors of society. Education in sciences would be offered to the students regardless of sex, while there would be the option of gender-specific practical, technical, vocational education for those girls whose families would be more inclined to send them to single-sex schools. Girls, after graduating from primary school, were admitted to these schools between 11 and 16 years of age (Akşit, 2013, p. 138). The day and evening schools aimed at raising women to become dutiful and enlightened citizens of the Republic, according to the Kemalist principle that women would be the counterpart of men in the overall modernization of the country. As Akşit rightfully comments in her extensive study, "Girls' Institutes, redefined the domestic as an area for patriotic activity." According to Akşit (2013, p. 134), girls were considered mainly as potential mothers and therefore imagined as sexless students who would be shaped in the image of the new Republic as healthy, beautiful, bodily fit and morally virtuous. According to the politics of education of the Republican State, the Turkish girl was to cling to her girlishness. "What was peculiar to the Turkish case was the invention of 'girlhood' to create a new balance between the public and private spheres and as a limbo between childhood and womanhood" (Akşit, 2013, p. 148). 
Hence, the modernizing mission of the state was inscribed in the education programs, which aimed at training the new citizens in the codes of conduct both in the public and the private spheres, hence shaped the appearance of the new elite, a model for the lower classes, as well. That is how young women became functionaries of the "cultural revolution" of Westernization (Akşit, 2005, p. 167). In these schools, general subjects as well as "scientific homemaking" courses such as cooking, cleaning and sewing, Western clothing styles and home decor were taught.

Researchers have stressed the significance of the reorganization of the private space for public appearance and rationalization of the domestic with the application of Taylorist principles of economization and efficiency in the making of "new women" and "new men" of the emergent middle classes of the modern Turkish Republic (Akşit, 2005, p. 159; Durakbaşa, 1998; Köksal, 1998; Navaro, 1991; Navaro-Yaşin, 2002; Özbay, 2000). Hence, on the one hand, there has been an emphasis on the productive capacity of women in the publications about the girls' vocational schools and, on the other hand, an equal celebration of the "new women" as the enlightened mothers and complementary partners to their husbands in the functional division of labour in between the sexes (Durakbaşa, 1998, p. 43; Köksal, 1998, p. 32).

Especially for lower classes in more conservative Anatolian cities, Girls' Institutes became a primary alternative to mixed schools and would work as an instrument for earning a basic income during and after their study period in these schools or in their counterpart in the evening schools. Another important mission of the Girls' Institutes was to reinforce the Turkish national identity besides its Westernizing and civilizing mission. Akşit refers to a few research projects and memoirs about the Girls' Institutes that were installed in provinces with dominantly Kurdish populations in which Turkification and socialization of Kurdish young women with Kemalist principles of national development became the main aims (Akşit, 2005, pp. 143-155).

By 1937, the number of full-time students reached 2000, while once the institutes were opened in the eastern provinces, evening school population stood at almost 8000 (Akşit, 2005, pp. 153). According to the third Education Council (1946), the aim of the Girls' Institutes was to create educated housewives with various skills of homemaking in order to become enlightened mothers of Turkish children. In this regard, the pedagogical purpose did not consist of preparing girls for high school and university education in these schools (Deniz, 2001, p. 27). Starting from 1938-39 the Girls' Institutes became part of a process of transformation into the so called Olgunlaşma Enstitüleri (Maturation Institutes) and Technical Lycees. Their curriculum became more like the regular high schools until about 1963-64. Although these schools were known informally as Girls' Institutes until the academic year of 1974-75, their programs, student profile, teacher profile and missions changed for improving employment of their graduates (Akşit, 2005, pp. 165-166; Toktaş, 1997, p. 20, 156).

Vocational Teaching Schools for boys and girls were named Erkek Teknik Öğretmen Okulu (1946-47) (Technical Teachers's Schools for Boys) and Kız Teknik Öğretmen Okulu (1947-48) (Technical Teachers' Schools for Girls) (Deniz, 2001, p. 27). These schools were the pools of women students who would become the main body of women professionals as teachers during the Republican Era.

\section{Village Institutes}

The educational policies of the Republic, ruled by the Republican People's Party as a single party, were outlined in the consulting bodies called Milli Eğitim Şuralsı (National Education Council) 
which considered youth-education (of boys as well as girls) as their first priority. They aimed at making the most efficient use of the specified inventory of schools, buildings, and classrooms with the least cost. In 1926, the National Education Council decided that girls and boys would be educated in the same classrooms in order to cut down expenses. The Village Institutes (Köy Enstitüleri) were the most striking example of a pedagogical program for development based on the cooperation of teachers, students and villagers in the practical tasks of building the infrastructure and producing agricultural products. The aim was to educate and train teachers as leaders of development in rural Turkey. Girls were also admitted to these schools although their numbers were always much fewer than the boys. Courses with practical content such as agriculture, carpentry and building were part of the curriculum alongside the basic theoretical courses in sciences and literature (Deniz, 2001, p. 18).

However, the Village Institutes were perceived as a political project of the Single Party Regime and even blamed for disseminating communism. Hence, they were shut down in 1954 by the Democrat Party government. The transition into multi-party politics enabled a space for the suppressed conservative opponents of the Kemalist Revolution who thought that the reforms, carried out during the transition into a secular state and society, had been too radical especially for disregarding the religious sentiments of the people. This was a turning point in Turkish political history, which had direct impact on today's educational policies representing a more conservative approach based on a synthesis of Turkism and Islamism, a right-wing Kemalism rather than a left-wing, radical, secular Kemalism.

As a result of the decisions of the $5^{\text {th }}$ National Education Council in 1954, the Village Institutes were closed and they were absorbed under the umbrella of Teaching Colleges for Primary School Teachers for the Villages (Deniz, 2001, p. 116). Especially after the 1980s, Turkey underwent a fast process of urbanization. The rate of population in the municipal boundaries of administrative centres exceeded rural population with $55 \%$ in 1985 and the over-all urban population reached $92.5 \%$ in 2017 . Girls have benefitted from the urbanization process by increasing their chances of having access to education of all levels in the urban centres. However, some civil initiatives argue for a revival of the Village Institutes ${ }^{4}$ especially for young girls who still exceed boys in school absenteeism and drop-out rates from schools and perhaps as well for women of older ages who have had very limited access to education and still make up the majority of the illiterate in specific geographical regions of rural Turkey.

\section{The outnumbering of Imam Hatip Schools as a backlash to radical secularism of the early Republic}

During the Struggle for National Independence, the government in Ankara also got involved in designing educational reforms in the area of religious education with a scientific approach. Both, the Constitution of 1921 and of 1924 stated Islam as the official religion of the Turkish state. It was not until 1927 that this statement was removed from the Constitution and in 1937 the principle of laicism was defined as the basis of the Turkish Republic. The Directorate of Religious Affairs, founded in 1924, functioned as a problematic institution in a secular Republic, to organize the religious services to people with a majority Muslim population, to administer the religious personnel, the building and care of the mosques and to have control over possible religious opposition to the Republic. Kemal Atatürk and the leaders of the Republic used Islam as a fundamental ingredient for maintaining the support of the people; that is, while fighting for the 
independence of people they also claimed to save Islam. Hence, in the early years of the Republic, religious education was an important subject in the curriculum.

During the radically secular policies of the Single Party rule of the Republican People's Party (RPP) in the 1930's, however, it was accepted that religious education should better be handled by the families; the last two Imam Hatip schools in İstanbul and Kütahya were closed in 1930 (Gözaydın, 2016, p.20). The religion course in primary schools was removed from the curriculum in 1939. During the multi-party period after the general elections of 1946, the RPP adopted more flexible policies in the area of religious education. Hence, in 1947 Imam Hatip courses for the functionaries of religious services started officially and, in 1949, religion was offered as an elective course in primary and middle schools, becoming a compulsory course under the Democrat Party government in 1951/52 (Deniz, 2001, p. 100). Imam-Hatip schools were re-opened and in 1959 Higher Islamic Institute was established in Istanbul. Even though it was not one of the policy recommendations of the 4th National Education Council in 1949, 7 religious schools in 7 provinces were opened in order to educate the imams, the preachers for the mosques, by a decision of the Committee of School Directors (Deniz, 2001, p. 30). Moreover, the Council of Ministers of State decided that the religion course should be mandatory in the middle school curriculum besides the primary education level in 1956.

After 1950, the number of Imam Hatip schools and the number of their students multiplied at a rate over the target in the Five-Year development plans. The National Education Councils, under the influence of the governing conservative ideology of the Democrat Party also promoted to increase the number of these religious schools. Considering that early specialization could lead to incorrect choices and extension of the normal education period, the Council decided in 1957 to turn the first three years of the vocational schools into secondary level general education schools. But, Imam Hatip schools were excluded from this systemic modification. On the contrary, the first three years of secondary education in Imam Hatip schools were extended until $80 \%$ of the total capacity of dormitories of these schools attracted rural Anatolian based families and their children (Deniz, 2001, p. 126).

More importantly for the education policy during the 1950s was the shift of the perception of the teacher as leader of the people regarding the mission to spread the Republican ideology and principles. This mission which had been given as a duty to the teachers in the early Kemalist Republic was not so accentuated any more. Also, the emphasis on "education for production" and "education for practical tasks of everyday living" changed. The reaction of the conservative opposition against the Kemalist education policies was mainly related to the most celebrated school model of Village Institutes during the Single Party period (Deniz, 2001, pp. 115116). Religious education was put onto the agenda of governments based on the idea that religious knowledge and sentiments would secure national solidarity and unity against communism and other political ideologies.

In the multi-party period after 1950, except for a brief time after the Constitution of 1961, conservative-nationalist ideologies have been most influential. Following their approach, laicism has been re-interpreted with the growing importance of religion as an ideology and its impact on education (Deniz, 2001, p. 117).

In the meantime, the Imam-Hatip schools which were founded as special schools to train civil servants for the running of mosques and other religious services, in accordance with the Unification of Education Law in 1924, were consolidated into the secondary education system 
through the 1973 Fundamental Law of National Education. This law redefined their functions in order to accommodate them to the regular high schools (lycees) that prepared students for higher education (Acar \& Ayata, 2002, pp. 91-92). In growing numbers and with an alternative program and philosophy of education to the secular, scientific and positivist principles of the official national education ideology set by the Kemalist Republic, they formed an alternative pool of schools for more devout and conservative sectors of society.

Moreover, since the Koran courses could be organized out of the control and surveillance of the Ministry of Education, religious education enabled the expansion of independent religious dissemination by a number of religious brotherhoods (tarikat), which had been abolished in 1925 through a crucial act of the Kemalist revolutionary state (Tan, 2008, pp. 117-118).

In 1974, during the coalition government of the National Salvation Party and the Republican People's Party, a new course titled Ahlak Bilgisi (Morality) was introduced as a mandatory course into the curriculum. Before the military coup in 1980, the number of Imam Hatip Schools had increased extremely and the number of High Islamic Institutes had reached nine. Finally, Article 24 of the Constitution of 1982 (accepted after the military coup) defined a new course titled "Religious Culture and Morality" to be a mandatory course in primary and secondary levels of education (Kaymakcan, 1996, pp. 91-107).

The main resistance to the decision of eight-year compulsory education at the basic level in 1997 came from these schools and the conservative parties which backed these schools for political, ideological reasons. The governing ideological and cultural principles of the education system in Turkey have been undergoing a transformation since the current ruling party, the AKP came to power in 2002, and for 16 years it has been in power as a single party unlike the coalition governments of the preceding period. Education policies under the AKP rule have been shaped by a combination of neoliberalism, conservatism and Islamism which sets it apart from the secularist founding ideology of the early Republican period. Consequently, one must talk about a restructuring of the education system based on a new founding ideology. The AKP has introduced several structural changes in the educational system since 2002 including: the revision of curriculum and textbooks; the introduction of Total Quality Management (TQM) and performance assessment of teachers; the abolishing of laws restricting religious education; and, dividing primary education into two stages. These structural changes reflect two aspects of the social policy regime of the AKP. On the one hand, the education system was left to the control of neoliberal policies. On the other hand, the party integrated its Islamist conservative ideology into the system (Inal, 2012).

With regard to educational policies, two phases can be identified under the AKP rule. While the first phase between 2002 and 2011 characterized by the introduction of neoliberal policies shows continuities with previous educational policies and their underlying principles, the second phase of the last six years has brought about more rapid and major changes in the education system during which overwhelmingly Islamist and conservative policies have been introduced.

In 2012, the compulsory primary schooling system was changed from a continuous EightYear system to an intermittent $4+4+4$ system and secondary schooling (8 years; grades $5-12$ ) became compulsory with a distance education option. Also, the schooling reform in 2012 reinitiated in practice the dual system of education, secular and religious, which had been abolished in 1924 with the transition to the secular Turkish Republic. With this reform, middle school 
sections (grades 6-8; ages 12-14) of religious schools that were closed in 1997 along with other vocational middle schools (because of the change into a continuous Eight-Year primary education) were re-opened (grades 5-8 today) replacing vocational middle schools or college preparation middle schools, which existed prior to the 1997 reform. Between 2012 and 2016, the number of religious middle schools (Imam Hatip Lycees) increased from 537 to 1,408 and the number of students attending those schools went up from 268,245 to 555,870 in 2015-2016. In 2017-2018, the number of Imam Hatip Lycees, was increased to 1,485; however, the number of students slightly dropped to 503,978 from 517,081 in the previous academic year (Eğitimsen Report, 2017-2018, p.4)

Official statistics of 2015-2016 of the Turkish Ministry of Education show that parents are slightly more willing to send girls to religious middle schools. About $53 \%$ of the students in religious middle schools are girls and $47 \%$ are boys (Bayhan \& Gök, 2017; Bayhan \& AratemurÇimen, 2018). The changes in the Turkish high school system in 2012 caused a sharp increase in the share of religious high schools while the percentage of vocational schools remained and college preparation schools decreased. The statistics of the Ministry of National Education of the last two years show that there are more girls $(56 \%)$ attending religious high schools than boys (44\%). This disparity is even bigger when looking at girls/boys-enrolment in open religious high schools: girls enrolled in open religious high schools in 2016-2017 academic year reached $66.3 \%$ while boys only 33.7\% (Bayhan \& Aratemur-Çimen, 2018). ${ }^{5}$

Acar and Ayata (2002) studied the (re)production of gender-based inequalities through educational institutions in secondary education in Turkey. Their study of school cultures in public, private and Imam-Hatip types of lycees in 1996-1997, found that gendered role patterns and codes of behaviour were mostly prevalent in sex-segregated single-sex Imam-Hatip schools. ${ }^{6}$ In these schools, "teachers advise girls and boys to choose their occupations in accordance with their fitrat (innate nature of creation), and not try to contradict it." The female students are encouraged to undertake jobs compatible with their nature, that is, "their fragile bodies should not be put under physical strain" and, furthermore, "the job should not necessitate interaction with men, and should be limited mostly to serving women" (Acar \& Ayata, 2002, p. 99).

\section{Vocational Schools}

Although there was an emphasis on the growth of the number of vocational schools and having more students in vocational schools rather than general lycees in the decisions of the National Education Councils, these decisions were not realized in practice (Deniz, 2001, pp. 125-126).

Tan (2008) draws attention to the gendered choice of female students in high schools that are not even named as belonging to girls such as Anatolian Vocational High Schools for Health Services, in which almost $80 \%$ of their students are female. On the contrary, in some areas such as Trade and Tourism High Schools or High Schools for Special Education for Disabled, female students have decreased in number. The report also acknowledges that girls from poor, extremely religious or conservative families are now more likely to study staying at home using the Open High School Program provided by the State. In fact, female students enrolled in such programs doubled in contrast to unbalanced numbers of female students in vocational training schools in general (Tan, 2008, p. 49).

There is a majority of female students in Girls' Technical Colleges, Anatolian High Schools for Health Services and Imam Hatip Schools. The outnumbering of girls in Imam Hatip Schools 
means that more families are encouraging their daughters into religious education in these schools which were initially designed to educate the imams and hatips (preachers) to be appointed to the mosques as civil servants. In fact, this is a gendered position for men, since women cannot become imams, they can only serve as preachers for the female audience and give auxiliary religious service under the Directorate of Religious Affairs. Although the total number of students in these schools decreased due to the shutting down in 1997 of their middle school sections and the application of a discouraging coefficient in the calculation of the university entrance exam points in the areas other than Islamic Theology, the decrease in the number of female students was much less than male students (Tan, 2008, pp. 50-51).

NGO's like Çağdaş Yaşamı Destekleme Derneği (Society for the Support of Civilized Life) and Anne Çocuk Eğitim Vakfı (Mother-Child Education Foundation) as well as secular left-wing political parties consider Imam Hatip Schools becoming part of general education rather than vocational education, as they had been in the first place, as a threat to the unified national education system based on secular principles. However, religious political parties with the support of the religiously oriented populace provided the push for the outnumbering of these schools and the formation of an alternative channel of education to the general education in other high schools.

In the academic year 2006-2007, female students in the technical vocational schools only reached $39 \%$ of the total students enrolled. Gender balance has not been achieved in these schools and vocational schools are still seen as mainly for male students when compared to the general high schools. Taking into account that almost half of the OECD countries have achieved gender balance or even female students have outnumbered male students, Tan (2008) maintains that the Turkish national education system has not yet been successful in altering the gender imbalance in secondary education as much as it has been accomplished in primary education.

Even though both Girls' Technical Schools and Boys' Technical Schools can enrol students from both sexes since 1975, the traditional gender distribution has not been altered to a great extent. The fact that the so-called Technical Vocational Schools for Boys are more than double of the number of the so-called Technical Vocational Schools for Girls also show that these schools are mainly meant for male students rather than female students. When it comes to examining gender distribution according to the type of vocational school, the trend displayed in the TUSIAD Report of 2000 has not changed much. In the Girls' Technical Vocational High Schools $80 \%$ of the students are still female and in Boys' Technical Vocational High Schools the percentage of girls is only $12 \%$. At the same time, statistics show that between 2000 and 2008 the number of students from the opposite sex have increased in these schools. Meaning, the gendered choices of families can be modified according to the conditions of employment and the rise of new areas of work which are not codified according to gender any more (Tan, 2008, pp. 49-50).

\section{General Evaluation of Women's Access to Education}

In Turkey, gender equality in education is mainly identified with the increase of the number of girls enrolled in secondary and primary schools, i.e. achieving numerical equality in education is considered an issue for policy makers. There has been some notable progress in the numbers of girls gaining access to all levels of education in recent years. The introduction of the Eight-Year compulsory education in 1997 has been one of the most important policies to increase girls schooling rates. While the net schooling ratio for girls at primary education level in 2001-2002 
was $88.4 \%$, it increased to $98.5 \%$ in $2011-2012$. After reaching its highest point of $99.6 \%$ in $2013-$ 2014, it has started to decline. In 2016-2017 the net schooling ratio for girls at primary education level was 91.2\% (MoNE, 2017). The reasons for this significant decline need to be explained.

The progress observed in the increase of enrolment rates at the secondary level of education over time is, however, quite striking. Since the academic year of 1994-95, this rate has gradually risen from $37 \%$ up to $79 \%$ in $2014-2015$ and to $83.4 \%$ in $2017-2018$. However, schooling rates in secondary education show serious regional variations. According to data regarding the academic year of 2014-15, the schooling rate reached 65\% in Northeast Anatolia and Centraleast Anatolia, $66 \%$ in Southeast Anatolia and $80 \%$ or higher in the other regions of Turkey (ERI Inclusivity Report, 2016, p. 28).

Women's schooling rates have shown great improvement at the secondary education level in recent years and it seems that the gender gap has been almost closed. In the school year of 2014-15, the net secondary education schooling rate for women in Turkey was $79.3 \%$ while this number was $79.5 \%$ for men. When schooling rates are analysed according to region, however, it can be observed that gender based inequality persists in some regions. The schooling rate of girls in secondary education in Southeast Anatolia, where the rate is usually the lowest, was $64.2 \%$ in 2015-2016 rising to $65.8 \%$ in 2016-2017. In Central-east Anatolia it increased from $64.4 \%$ to $66.8 \%$ in the same year. The gender gap still exists in a number of points; that is, boys' enrolment rate is higher than that of girls (MoNE, 2017).

Another important indicator is the completion rate being still relatively lower for girls than for boys. Generally, the handling of questions of girls' education only in terms of enrollment seems too shortsighted: according to the teachers, many children do not appear in the classroom. Girls' non-attendance is higher than boys, even if they get enrolled in return for the direct cash payment offered by the Ministry of Education. Many teachers state: "We do not record all the non-attendance for we don't want the girls to drop out of school or repeat the class. Boys work as seasonal labourers. They go to work in the fields or the forest. However, girls' labour is always needed... Apart from other work, they have to look after their siblings, when their mother is occupied somehow, or do housework or give care to the ill" (Tan, 2007; Tan, 2008, p. 45).

Socioeconomic status is a variable that crosscuts other variables relating to inclusive education. Research findings show that socioeconomic status has a significant effect on continuity in school. Poverty prevents children from continuing their studies ${ }^{7}$ because of the need of their labour in domestic chores and/or as a child worker working outside. Therefore, evaluation of how schooling rates and academic success in children is associated with household income levels and the educational backgrounds of parents is also important (ERI Inclusivity Report, 2016, p. 26).

Education analysts insist that the gender equality in education comprises more than the number of girls accessing education. Cin (2017, pp. 9-11) argues in favour of a gender justice approach that goes beyond the numerical indicators of gender asymmetry and balance to a qualitative study of norms, relationships and practices both in the education system and in the gendered structures of society that produce and reproduce gender inequalities in all spheres of social life. It is within such a framework of analysis that most of the projects and campaigns carried out by the Ministry of Education ${ }^{8}$ in Turkey, in partnership with other governmental and non-governmental organizations, fall short of more sustainable improvement in education and empowerment of girls and women, despite their highly positive outcomes on the rates of 
schooling of girls at all levels of education in the recent years. Besides raising the school enrolment rates of girls, there are other important factors related to girls' schooling experiences within and outside the schools, gender and social relations within and around the school, the quality of education girls receive, or how market and family relations impact girls' schooling. In addition, family size and mothers' educational level and ability to speak Turkish (for Kurdish mothers) are significant predictors of girls' school participation. According to social researchers in this area, the gendered nature of education in Turkey persists, creating inequality problems in different ways. Cin addresses three areas of significant inequality: (1) inequality of girls' access to education; (2) problems with curriculum and education system; and (3) teachers' underrepresentation in managerial posts and gendered ways of teaching (Cin, 2017, pp. 9-11).

The differences between boys and girls in terms of educational attainment indicate that projects should have specific targets among the female population. Social policy consultants as well as social scientists have argued that income per capita for the household is more important for girls' schooling in Turkey particularly since there is a son preference. Given that females have a more skewed distribution of schooling in Turkey, policies should aim to remedy the obstacles that restrain girls with specific backgrounds from schooling (Duman, 2010, pp. 243-258).

Secondary education is an important step in the transition to higher education and professional life. The low levels of both women's participation in higher education and their employment rates may therefore be seen as directly related to how they access secondary education and the quality of the education they receive. When we look at the gender distribution in university and high school education in Turkey, nearly 50\% of the graduates in 2015-16 are women. The graduation rate from tertiary education for women over 25 was $14.2 \%$ and it was $18.8 \%$ for men (TUIK, 2017). These figures show that once girls have access and equal opportunity to get further education after the basic level of education and secondary education, they successfully carry on with their education to the tertiary level as well as the master's and doctorate study almost equally to the male students. (TÜsiAD Women Matter 2016 Report, p. 21). However, Turkey has the lowest female labour force participation rate of OECD countries. Women's employment rate for over 15 years old was $28 \%$ and men's employment rate for over 15 was $65.1 \%$ in 2017 (TUIK, 2017).

\section{Conclusion}

From these statistical indicators of gender asymmetry, it can be deduced that, despite improving girls' access to various levels of education, it remains unclear to what extent women are really empowered to experience school environments as well as courses and course material free from gender stereotypes, discriminatory practices and gendered power hierarchies or authority structures. The constant changes in the Turkish education system over the last 20 years, have baffled the students, the teachers and the school administrators jeopardizing school cultures and students' sense of confidence and motivation in the learning process. Because of the traditional and patriarchal norms in Turkish society, girls and women face more obstacles than men in order to complete education and start employment. Therefore, the school environment with all its components should provide qualified education coupled with a supportive network of social relations with female teachers as role models, with classmates as learning companions and administrators who reward self-accomplishments rather than inhibit personal growth of students. We have tried to describe a number of school models implemented during the early 
Republic which functioned as an alternative space for women for self-enrichment and empowerment. Studies about the textbooks in early Republican era (1923-1950) claim that they were much more egalitarian in terms of gender when compared to the examples in the later political historical period between 1950 and 2000. Although the textbooks have been reviewed to omit gender stereotypes and there has been improvement in terms of providing gender equality in texts and visual material used in textbooks, they have not been totally cleared of sexist discrimination (Gümüşoğlu, 1998; Gümüşoğlu, 2005; Gümüşoğlu, 2008; Çayır, 2004).

It should be acknowledged that the agreements Turkey signed during the quasi process of Turkey's entry into the European Union, international agreements such as CEDAW that Turkey has to accord with and other global fund-giving policy organizations such as UNESCO or the World Bank with which the Ministry of Family and Social Policy under the AKP rule, has to work in various projects towards gender equality, exert pressure on the policy makers, in the positive sense. Like the previous governments, the AKP government had to attend to the universal principles of gender equality, women's empowerment, and not disregard the rights of LGBTI+ individuals. In the area of education there are very strong civil initiatives and NGO's such as ÇYDD (Çağdaş Yaşamı Destekleme Derneği, Society for the Support of Civilized Life), AÇEV (Anne Çocuk Eğitim Vakfı, Mother-Child Education Foundation), and ERG (Eğitim Reformu Girişimi, Education Reform Initiative) who work in partnership with local, national and global political bodies and nongovernmental organizations, which both keep close watch and record of gender inequalities in the country and try to cooperate in large-scale projects to bring remedies to gross problems of inequality.

The overview of the history of Turkish education system from a gender-sensitive point of view presented in this paper aims at shedding light on the complexity of the issues as current problems of gender asymmetry in education cannot be fully addressed only in terms of gender inclusivity of the system as inclusivity does not guarantee equality. The Turkish education system has been under attack of neo-liberal policies of extreme privatization and marketization ${ }^{9}$ coupled with desperate attempts to restore the degeneration in values with further Islamification ${ }^{10}$ of the curriculum ${ }^{11}$ in the so-called package of "Values Education" ${ }^{12}$ courses, and giving further possibility and space to the engagement and intervention of private religious foundations into the secular public education system.

\section{References}

Acar, F. (1996). Türkiye'de Kadın Akademisyenler: Tarihsel Evrim ve Bugünkü Durum. Akademik Yaşamda Kadın. In H. Coşkun, (Ed.), Türk ve Alman Üniversitelerinde Kadın Kariyerlerinin Karşılaştırılması (pp. 75-87). Ankara: Türk-Alman Kültür İşleri Kurulu.

Acar, F. \& Ayata, A. (2002). Discipline, Success and Stability: The Reproduction of Gender and Class in Turkish Secondary Education. In D. Kandiyoti, \& A. Saktanber, (Eds.), Fragments of Culture, The Everyday of Modern Turkey (pp. 90-111). London and New York: I.B. Tauris.

Akçasoy, i. (2014). Makbul Vatandaş İnşasında Vites Büyütmek: Eğitimin Sünnileştirilmesi. Ayrıntı Dergi, 7, Retrieved from http://ayrintidergi.com.tr/sayi-7-kasim-aralik-2014/ 
Akşit, E. E. (2013). Girls' Institutes and the Rearrangement of the Public and the Private Spheres in Turkey. In D. Köksal \& A. Failierou (Eds.), A Social History of late Ottoman Women: New Perspectives (pp. 133-149). Leiden: Brill.

Akşit, E. E. (2005). Kızların Sessizliği, Kız Enstitülerinin Uzun Tarihi. İstanbul: İletişim.

Akyüz, Y. (2014). Türk Eğitim Tarihi (20th ed.). Ankara: Pegem Akademi.

Arat, Z. (1998). Kemalizm ve Türk Kadını. In A. Berktay Hacımirzaoğlu (Ed.), 75 Yılda Kadınlar ve Erkekler (pp. 51-70). İstanbul: Tarih Vakfı \& İş Bankası.

Arat, Z. (1999). Educating the Daughters of the Republic. In Z. Arat (Ed.), Deconstructing Images of the Turkish Woman (pp.157-183). New York: Palgrave Macmillan.

Aybek, Ş. (2018). Rakamlarla 2016-2017 Yılı Eğitim Öğretimi, retrieved from www.egitimajansi.com 06.06.2018.

Baloğlu, Z (1990). Eğitim Raporu. İstanbul: TüsiAD.

Bayhan, S. \& Aratemur-Çimen, C. (2018). Gender in Turkey's 2017 Curriculum Reform and Its Textbooks. Unpublished paper presented at Gender and Education Conference. 11-13 May 2018. İstanbul: Sabancı University.

Bayhan, S. \& Gök, F. (2017). Education policy in an era of neoliberal urbanisation: a case study of Istanbul's school relocations. British Journal of Sociology of Education, 38:4, 581-595. doi: 10.1080/01425692.2015.1113858

Berktay Hacımirzaoğlu, A. (1998). 75 Yılda Kadınlar ve Erkekler. Istanbul: Tarih Vakfı \& İş Bankası.

Cin, F. M. (2017). Gender Justice, Education and Equality Creating Capabilities for Girls' and Women's Development. Lancaster: Lancaster University Press.

Çaha, Ö. (2010) Sivil Kadın, Türkiye'de Kadın ve Sivil Toplum. Ankara: Savaş Yayınevi.

Çakır, S. (1990). Osmanlı Kadın Hareketi. İstanbul: Metis.

Çakır, S. (1991). Osmanlı Kadın Dernekleri. Toplum ve Bilim, 53, 139-157.

Çakır, S. (2007). Feminism and Feminist History-writing in Turkey- The Discovery of Ottoman Feminism. Aspasia, 1, 61-83.

Çayır, K. (2014). "Biz" kimiz? Ders kitaplarında kimlik, yurttaşlık, haklar. Istanbul: Tarih Vakfı.

Çukur, D. (2008). Köy Enstitüleri Eğitim Modelinin Hedeflediği İnsan Tipi ve Türkiye'de Yapılmış Tezlerde Köy Enstitüleri. Toplum ve Demokrasi, 2(4), 151-162.

Demirdirek, H. and Şener, Ü. (2014). 81 il için toplumsal cinsiyet eşitliği karnesi. Retrieved from http://www.tepav.org.tr/upload/files/haber/1391012395-

8.81_II_icin_Toplumsal_Cinsiyet_Esitligi_Karnesi_Taslak.pdf

Deniz, M. (2001). Milli Eğitim Şuralarının Tarihçesi, Unpublished master's thesis. Süleyman Demirel University.

Duman, A. (2010). Female Education Inequality: Factors Affecting Girls Schooling. International Journal of Education Economics and Development, 3, 243-258.

Durakbaşa, A. (1987). The Formation of Kemalist Female Identity: A Historical-cultural Perspective, Unpublished master's thesis, İstanbul: Boğaziçi University.

Durakbaşa, A. (1998). Cumhuriyet Döneminde Modern Kadın ve Erkek Kimliklerinin Oluşumu: Kemalist Kadın Kimliği ve "Münevver Erkekler", In A. Berktay Hacımirzaoğlu, (Ed.), 75 Yılda Kadınlar ve Erkekler. İstanbul: Tarih Vakfı \& İş Bankası.

Eğitim-Bir-Sen (2017). Gecikmiş Bir Reform: Müfredatin Demokratikleştirilmesi. Retrieved from http://www.ebs.org.tr/ebs_files/files/yayinlarimiz/gecikmis_bir_reform_mufredatin_d emokratiklestirilmesi.pdf 
Eğitim-Bir-Sen (2011a). 18. Milli Eğitim Şurası ve Sendikamı. Retrieved from http://www.egitimbirsen.org.tr/detay.php?id=137951\&cid=52\&keyword=\%FEura

Eğitim-Bir-Sen (2011b). 220 Kararın Alındığı Şura'ya Damgamızı Vurduk. Retrieved from http://www.egitimbirsen.org.tr/detay.php?id=137888\&cid=52\&keyword=\%FEura

Eğitim-Sen Report (2018) 2017-2018 Eğitim Öğretim Yılı Sonunda Eğitimin Durumu, retrieved from www.egitimsen.org.tr, 07.06.2018

Eğitim Reformu Girişimi (2017). Education Monitoring Report 2017. Retrieved from http://en.egitimreformugirisimi.org/wp-content/uploads/2017/03/EIR2016-

17.ENG_30.03.18.web_.pdf

ERI Inclusivity Report (2016). A Situation Analysis of Inclusive Education in Secondary Schools in Turkey. Retrieved from http://en.egitimreformugirisimi.org/inclusive-education-study$2 /$

Ertürk, H. S. (1997). Vocational and Technical Education in the Turkish Educational System. In G. Yıldıran \& J. Durmin (Eds.), Recent Perspectives on Turkish Education (pp. 99-112). Indiana: Indiana University Publications.

Gelişli, Y. (2005). Education of Women from Ottoman Empire to Modern Turkey. Bulgarian Historical Review, 1-2, 104-119.

Gelişli, Y. (2014). Türkiye'de Kadın Eğitiminin Bugünkü Durumu. Akademik Bakış Dergisi, 40, 1-20. Göktürk, D., Güvercin, G. \& Seçkin, O. (2012). The New Stream of Trade Unionism: The Case of Eğitim-Bir-Sen in Turkey. In K. İnal \& G. Akkaymak (Eds.), Neoliberal Transformation of Education in Turkey: Political and Ideological Analysis of Educational Reforms in the Age of the AKP (pp. 109-123). New York, NY: Palgrave Macmillan.

Gözaydın, İ. (2016) Diyanet- Türkiye Cumhuriyetinde Dinin Tanzimi, İstanbul: Iletişim.

Gümüşoğlu, F. (1998). Ders Kitaplarında Toplumsal Cinsiyet. In A. Berktay Hacımirzaoğlu (Ed.), 75 Yılda Kadınlar ve Erkekler (pp.101-128). İstanbul: Tarih Vakfı \& İş Bankası.

Gümüşoğlu, F. (2005). Ders Kitaplarında Toplumsal Cinsiyet (2nd ed.). İstanbul: Çağdaş Eğitim Vakfı.

Gümüşoğlu, F. (2008). Ders Kitaplarında Toplumsal Cinsiyet. Toplum ve Demokrasi, 2(4), 39-50.

Gümüşoğlu, F. (2017). Sözlü ve Yazılı Belgeler Işığında Cılavuz Köy Enstitüsü. İstanbul: İş Bankası Kültür.

Inal, K. (2012). The Educational Politics of the AKP: The Collapse of Public Education in Turkey. In K. Inal \& G. Akkaymak (Eds.). Neoliberal Transformation of Education in Turkey: Political and Ideological Analysis of Educational Reforms in the Age of the AKP (pp. 18-30). New York, NY: Palgrave Macmillan.

Kaya, A. (2014). Islamisation of Turkey under the AKP Rule: Empowering Family, Faith and Charity. South European Society and Politics, Published online: 11 Dec 2014. doi:10.1080/13608746.2014.979031

Kaymakcan, R. (1996). Religious Education in the Multi-Party Period in Turkey. East/West Education, 17(1/2), 91-107.

Köker, E. (1988). Türkiye'de Kadın, Eğitim ve Siyaset: Yüksek Öğrenim Kurumlarında Kadının Durumu Üzerine Bir inceleme. Unpublished doctorate thesis. Ankara: Ankara University.

Köksal, D. (1998). Yeni Adam ve Yeni Kadın: 1930'lar ve 1940'larda Kadın, Cinsiyet ve Ulus. Toplumsal Tarih, 51, 31-35. 
Kurnaz, Ş. (1991) Cumhuriyet Öncesinde Türk Kadını (1839-1923), Ankara: Başbakanlık Aile Araştırma Kurumu Yayınları.

Ministry of National Education (2017). National Education Statistics Formal Education 2016-2017. Ankara: MoNE.

Ministry of National Education (2016). National Education Statistics Formal Education 2015-2016. Ankara: MoNE.

Navaro, Y. (1991). Using the Mind at Home: The Rationalization of Housewifing in Early Republican Turkey, 1928-1940. Unpublished B.A Thesis, University of Brandeis.

Navaro-Yaşin, Y. (2002). Evde Taylorizm: Türkiye Cumhuriyeti'nin illk Yıllarında Evişinin Rasyonelleşmesi (1928-1940). Toplum ve Bilim, 84, 51-74.

OECD EAG Country Report, 2017

Öncü, A. (1979). Uzman Mesleklerde Türk Kadını. In N. Abadan-Unat (Ed.), Türk Toplumunda Kadın, (pp.253-267), Ankara: Sosyal Bilimler Derneği.

Öncü, A. (1981). Turkish Women in the Professions: Why so Many?. In N. Abadan-Unat et al. (Eds.), Women in Turkish Society (pp. 181-193). Leiden: Brill.

Özbay, F. (1999). Gendered Space: A New Look at Turkish Modernisation. Gender \& History, 3 (11), 555-587.

Polat, E. \& Madra, A. (2018). Gender Gaps in Student Achievement in Turkey Evidence from PISA 2015 and TIMSS 2015. Retrieved from http://en.egitimreformugirisimi.org/issue/gender-gaps-in-student-achievement-inturkey-evidence-from-pisa-2015-and-timss-2015/

Tan, M. (1981). Atatürkçü Düşünüş ve Karma Eğitim. Uluslararası Atatürk Konferansının Belgeleri. İstanbul: Boğaziçi Üniversitesi Matbaası.

Tan, M. (2008). Türkiye'de toplumsal cinsiyet eşitsizliği: Sorunlar, öncelikler ve çözüm önerileri. Istanbul: KAGIDER and TÜSIAD. Retrieved from http://www.tusiad.org:7979/FileArchive/KADINRAPOR.pdf

Tan, M. (2007) Women, Education and Development in Turkey, Education in 'Multicultural' Societies - Turkish and Swedish Perspectives, eds. M. Carlson, A. Rabo \& F. Gök, Swedish Research Institute in Istanbul, Transactions, vol.18, pp. 107-122.

Tansel, A. (2002). Determinants of School Attainment of Boys and Girls in Turkey: individual, household, and community factors. Economics of Education Review, 21, 455-470.

Tansel, A. (2004). Education and Labour Market Outcomes in Turkey. Report prepared for World Bank. Retrieved from http://siteresources.worldbank.org/INTTURKEY/Resources/3616161142415001082/Education_Labor_by_Tansel.pdf

Thornberg, R. \& Oğuz, E. (2016). Moral and Citizenship Educational Goals in Values Education: A Crosscultural Study of Swedish and Turkish Student Teachers' Preferences. Teaching and Teacher Education, 55, 110-121. doi:10.1016/j.tate.2016.01.002

Toktaş, Ş. (1997). Gender Awareness: A Study of Women Teachers and Academicians Who are Graduates of Girls' Institutes 1960-70. Unpublished master's thesis. Ankara: Women's Studies Program, Middle East Technical University.

Turkish Statistical Institute (2017). İstatistiklerde Kadın 2017. Retrieved from http://www.tuik.gov.tr/PreHaberBultenleri.do?id=27594 
United Nations Development Programme (2009). Human Development Report 2009 Overcoming Barriers: Human Mobility and Development, New York: UNDP.

TÜSiAD (2000). Kadın-Erkek Eşitliğine Doğru Yürüyüş: Eğitim, Çalışma Yaşamı ve Siyaset. İstanbul: Lebib Yalkın Yayınlar

TÜSIAD. (2016). Women Matter Turkey 2016 Report, Retrieved from https://tusiad.org/tr/yayinlar/raporlar/item/9643-women-matter-turkey-2016-reportturkey-s-potential-for-the-future-women-in-business

Üstel, F. (2016). "Makbul Vatandaş"ın Peşinde: Il. Meşrutiyet'ten Bugüne Vatandaşlık Eğitimi (7th ed.). İstanbul: Illetişim.

Yıldıran, G. (1997). An Overlook at the Turkish Educational System. In G. Yıldıran \& J. Durmin (Eds.), Recent Perspectives on Turkish Education (pp. 1-13). Indiana: Indiana University Turkish Studies Publications.

${ }^{1}$ She worked as a professor of sociology (2009-2016) and served as the chairperson of the Sociology Department for 6 years at Marmara University, Istanbul. She was forced to retire in December, 2016, because of signing the Academics for Peace Petition. She worked as a guest-lecturer at the Social History Department, Vienna University, for a term, 2 October-29 December, 2017. She is a member of Istanbul Solidarity Academy, one of the support groups formed by academics at risk in Turkey.

${ }^{2}$ She worked as a lecturer at Marmara University, Sociology Department from 2008 until her dismissal on 7th February 2017 due to her signing of the Academics for Peace Petition. Currently, she is a member of Istanbul Solidarity Academy and Academics with No Campus.

${ }^{3}$ The distribution of women in natural and social sciences have become more like the gender-specific model in the West in more recent years (Acar, 1999; Durakbasa, 1998).

${ }^{4}$ For example, an association with the name Yeni Kuşak Köy Enstitüleri Derneği (Association for the New Generation of Village Institutes) is quite active in the public scene with conferences and publications.

${ }^{5}$ In 2016-2017 the total number of students in the intermediary and lycee level of Imam Hatip schools have increased to $1,291,426$. This number was 71,100 in 2002 when AKP came to power. The number of Imam Hatip schools at intermediary level increased to 2,777 this year from the number of 1,961 last year. The number of Imam Hatip Lycees increased to 1,408 from 1,149. In 2016-2017 academic year, of all the students at the secondary education, 52.8\% were in general lycees, $35.6 \%$ were in vocational schools under which İmam Hatip Lycees are also placed. $11.5 \%$ of the students attend Imam Hatip Lycees. We see that the number of Private schools and Imam Hatip schools increased to a great extent, in 2016-2017. The highest increase is in the number of intermediary Imam Hatip schools. Also, there has been an increase in the number of students who follow the Open Lycee courses. Retrieved from www.egitimajansi.com 06.06.2018; (Aybek, 2018).

${ }^{6} \mathrm{~A}$ right-wing trade union of teachers, Eğitim-Bir-Sen (Union of Unity of Educators) recommended de-segregation and abandonment of co-education in secondary level education. Eğitim-Bir-Sen was established in 1992 and it has become one of the largest public employees' trade unions under the AKP rule. While the number of Eğitim-Bir-Sen members was 18,028 in 2002, it increased to 195,695 in 2011, and to 420,000 members in 2017. Eğitim-Bir-Sen has had a close relationship with the AKP. According to one of their reports, the union aims to cherish the ideal of nationalism and legitimizes the AKP rule through its messages and potential constituents (Göktürk, Güvercin, and Seçkin, 2012, pp. 116).

${ }^{7}$ Another policy put in place to lower absentee rates is the provision of Conditional Cash Transfers for Educational Assistance (CCTs). CCTs are provided by the Ministry of Family and Social Policies (MoFSP) to poor families whose children aged 6-17 years are unable to take advantage of educational services due to economic difficulties, under the condition that they send their children to school regularly.

${ }^{8}$ Increasing girls' access to education is included in the 2015-2019 Strategic Plan of MoNE as well. An important step taken by the Ministry to improve the schooling rates of girls is the Project to Increase School Enrolment Rates Especially for Girls (ISEG). This project was completed in the year 2011, in coordination with the Ministry of Labour and Social Security and with the support of the European Union. As part of this project, field research was carried 
out in 16 pilot provinces with low enrolment rates in schools, high dropout rates, and large gaps between the enrolment rates of girls and boys (Tan, 2008).

${ }^{9}$ The number of private schools has increased 10 times and the number of students in these schools has increased 12 times as much as it was 5 years ago. In the year 2016-2017, 1472 private education institutes have turned into private lycees.

${ }^{10}$ Eğitim-Sen (left-wing trade union of teachers) founded in 1995, which has 93,143 members in 2017, is one of the significant organizations critical of the educational policies of the AKP government. Eğitim-Sen has lost some of its members because of the academics and teachers expelled from their offices after the coup attempt on July 15, 2016. Eğitim-Sen reports some recommendations made in the 19th National Educational Council (2014), which hint at further Islamization of education: (a) In order to give/impose love of God to the students and introduce them to the ideas of heaven and hell "religious values education" should be introduced at the pre-primary education level; (b) "Values education" should be considered as an important part of the education process; (c) Fairytales, stories, poems belonging to Anatolian and Islamic culture need to be included in educational materials such as textbooks at the preprimary and primary education level; (d) compulsory religious courses should be introduced at Grade 1, 2 and 3; (e) compulsory religion courses should be increased to two hours at the secondary education level. Retrieved from egitimsen.org.tr/egitimin-dinsellestirilmesi-ve-sura-kararlari-sunumu

${ }^{11}$ The 2017 curriculum was passed under the current state of emergency conditions and has been criticised by scholars, secular groups, education rights groups and women's groups for its Islamic character, lack of respect for religious differences and gender equality. Illker Akçasoy (specialist, in Eğitim-Sen, leftwing trade union for teachers) describes the widening scope of religious courses within the curricula at the primary level of education saying: "This is what I want to indicate that a student in 12 years of his or her primary education in regular schools can get 1476 hours of religion courses, whereas he has the option of taking only 144 hours of philosophy and 72 hours of sociology courses as electives." He also maintains that philosophy and sociology courses have also gained some Sunni Islamic content in the meantime (Akçasoy, 2014).

12 "Values education" can be defined as the aspect of educational practice in which moral or political values, as well as norms, dispositions, and skills grounded in those values, are mediated to or learned by students" (Thornberg and Oğuz, 2016). In the current educational policy agenda of AKP, it means Islamization of content of the curricula and indoctrination of students and teachers into a single vein of interpretation of Islamic teachings. 